\title{
FAKTOR-FAKTOR YANG MEMPENGARUHI PERGERAKAN INDEKS HARGA SAHAM SEKTORAL PERTANIAN DI BURSA EFEK INDONESIA PERIODE 2014-2018
}

\author{
Chikal Galih ${ }^{1)}$, Lies Sulistyowati ${ }^{2)}$ \\ 1) Departemen Sosial-ekonomi Pertanian,Universitas Padjadjaran, \\ chikalgalihk@gmail.com \\ ${ }^{2)}$ Departemen Sosial-ekonomi Pertanian, Universitas Padjadjaran, \\ lies.sulistyowati@unpad.ac.id
}

\begin{abstract}
Abstrak
Indeks Harga Saham Gabungan (IHSG) adalah salah satu indikator perkembangan investasi saham di Indonesia, di mana ada indeks sektor yang mewakili perusahaan publik, salah satu indeks sektoral adalah Indeks Harga Saham Sektoral (IHSS) Pertanian. Fenomena yang terjadi pada periode 2014-2018 adalah tingkat pengembalian investasi di IHSS Pertanian menjadi yang terburuk dibandingkan dengan IHSG dan sektor lainnya sebesar $33,47 \%$. Tujuan dari penelitian ini adalah untuk mengidentifikasi faktor-faktor yang mempengaruhi pergerakan IHSS Pertanian periode 2014 hingga 2018 secara bulanan. Analisis yang digunakan adalah analisis Ordinary Least Square (OLS) untuk mengidentifikasi faktor-faktor yang mempengaruhi pergerakan IHSS Pertanian. Hasil penelitian menunjukkan bahwa inflasi, nilai tukar USD/IDR, suku bunga bank sentral, IHSG, harga minyak kelapa sawit, dan harga emas berpengaruh signifikan terhadap pergerakan IHSS Pertanian dengan nilai pengaruh $88,6 \%$.

Kata kunci: Indeks Harga Saham Sektoral Pertanian, Return Saham, Makroekonomi, Ordinary Least Square (OLS)
\end{abstract}

\begin{abstract}
Jakarta Composite Index (IHSG) is an indicator of the development of stock investment in Indonesia, where there are indices of sectors that represent public companies, one of the sectoral indices is the Sectoral Stock Price Index (IHSS) of Agriculture. The phenomenon that occurred in the 2014-2018 period was the level of investment return in the IHSS of Agriculture being the worst compared to the IHSG and other sectors by $-33.47 \%$. The purpose of this study is to identify the factors that influence the movement of IHSS of Agriculture for the period of 2014 up to 2018 on monthly base. The analysis used is Ordinary Least Square (OLS) analysis to identify the factors that influence the movement of IHSS of Agriculture. The results showed that inflation, USD/IDR exchange rate, central bank interest rate, IHSG, palm oil prices, and gold prices significantly influence the movement of IHSS of Agriculture with an influence value of $88.6 \%$.
\end{abstract}

Keywords: Agricultural Sectoral Stock Price Index, Stock Return, Macroeconomics, Ordinary Least Square (OLS). 


\section{Pendahuluan}

Pasar modal melakukan dua fungsi penting dalam perekonomian nasional, yaitu fungsi ekonomi dan fungsi keuangan. Hal ini juga berarti bahwa perusahaan mempunyai peluang dan fasilitas untuk mendapatkan modal tambahan dari investor melalui pasar modal. Di sisi yang lain, masyarakat bisa turut berinvestasi melalui pasar modal dalam instrument keuangan, antara lain: saham, reksadana, obligasi dan SBN (Surat Berharga Negara).

Berbagai instrumen keuangan jangka panjang, baik ekuitas (saham), obligasi (obligasi), reksadana, instrumen derivatif dan instrumen lainnya, dapat diperdagangkan dalam Pasar Modal. (BEI, 2017). Lembaga yang berperan sebagai pasar modal di Indonesia adalah Bursa Efek Indonesia (BEI). BEI adalah lembaga yang berperan dalam mengatur dan menyediakan fasilitas sistem perdagangan efek di pasar modal Indonesia.

Produk dari Bursa Efek Indonesia salah satunya adalah saham. Indeks harga saham adalah indikator utama yang menggambarkan pergerakan saham tercatat secara keseluruhan yang memberikan informasi tentang perkembangan pasar saham. Indeks Harga Saham Gabungan (IHSG) menggunakan semua perusahaan yang terdaftar di BEI sebagai komponen perhitungan indeks. Sedangkan Indeks Harga Saham Sektoral (IHSS) dalam perhitungannya menggunakan semua emiten yang masuk dalam setiap sektor sehingga perkembangan masing-masing sektor bisa diketahui. IHSG terdiri dari sembilan indeks sektoral, yaitu: pertanian, (2) pertambangan, (3) industri dasar dan kimia, (4) berbagai industri, (5) industri barang konsumsi, (6) properti dan real estat, (7) transportasi dan infrastruktur, (8) keuangan, dan (9) perdagangan, jasa dan investasi (Bursa Efek Indonesia, 2010).

Fenomena yang terjadi selama periode 2014-2018 adalah tingkat pengembalian IHSS Pertanian yang menunjukkan kinerja terburuk jika dibandingkan dengan IHSG dan indeks sektoral lainnya. Tabel 1. menunjukkan perbandingan tingkat pengembalian antara IHSS Pertanian dan pengembalian IHSG dan indeks sektoral lainnya.

Tabel 1

Return IHSG dan Indeks Sektoral Periode 2014-2018

\begin{tabular}{|c|c|c|c|c|c|}
\hline Indeks & $\begin{array}{c}\text { Return } \\
2014-2015 \\
(\%)\end{array}$ & $\begin{array}{c}\text { Return } \\
2015-2016 \\
(\%)\end{array}$ & $\begin{array}{c}\text { Return } \\
2016-2017 \\
(\%)\end{array}$ & $\begin{array}{c}\text { Return } \\
2017-2018 \\
(\%)\end{array}$ & $\begin{array}{c}\text { Return } \\
\mathbf{2 0 1 4 - 2 0 1 8} \\
(\boldsymbol{\%})\end{array}$ \\
\hline IHSG & -11.69 & 14.71 & 24.77 & $-6.23 \%$ & $\mathbf{1 8 . 5 2}$ \\
\hline Pertanian & -25.91 & 11.83 & -15.44 & $-5.05 \%$ & $\mathbf{- 3 3 . 4 7}$ \\
\hline Pertambangan & -42.60 & 79.57 & 41.26 & $-10.84 \%$ & $\mathbf{2 9 . 8 2}$ \\
\hline Industri Dasar & -24.26 & 34.33 & 39.11 & $11.12 \%$ & $\mathbf{5 7 . 2 7}$ \\
\hline Lain-lain & -15.97 & 20.53 & 6.74 & $-1.33 \%$ & $\mathbf{6 . 6 5}$ \\
\hline Konsumer & -0.24 & 7.01 & 23.34 & $-10.38 \%$ & $\mathbf{1 8}$ \\
\hline Properti dan & -9.95 & 10.53 & 3.15 & $-16.91 \%$ & $\mathbf{- 1 4 . 6 9}$ \\
\hline Real Estate & -13.14 & 4.31 & 10.61 & $-8.47 \%$ & $\mathbf{- 8 . 2 7}$ \\
\hline Infrastruktur & -6.54 & 17.77 & $46.02 \%$ & $0.02 \%$ & $\mathbf{6 0 . 7 3}$ \\
\hline Keuangan & -9.63 & 8.83 & $11.75 \%$ & $-18.86 \%$ & $\mathbf{- 1 0 . 8 2}$ \\
\hline Perdagangan & & & & \\
\hline
\end{tabular}

Sumber: Otoritas Jasa Keuangan, 2018

Selama periode 2014-2018, pengembalian sektor pertanian berada pada peringkat terendah dibandingkan dengan sektor lainnya pada minus $33,47 \%$. 
Keputusan investor sangat dipengaruhi oleh nilai pengembalian yang diterima. Return adalah indikator utama kemampuan perusahaan untuk menciptakan nilai bagi investor dalam bentuk pembayaran dividen atau capital gain. Dalam menentukan return saham selain dipengaruhi oleh kinerja perusahaan juga dipengaruhi oleh faktor eksternal. Faktorfaktor ini termasuk faktor ekonomi makro dan termasuk faktor eksternal lainnya, seperti adanya krisis ekonomi (Kurniadi et al., 2014).

Faktor makro adalah faktor yang berada di luar perusahaan, tetapi memiliki pengaruh terhadap peningkatan atau penurunan kinerja perusahaan baik secara langsung maupun tidak langsung. Faktor makro terdiri dari makro ekonomi non makro dan makro. Faktor ekonomi makro yang secara langsung dapat mempengaruhi kinerja saham dan kinerja perusahaan termasuk suku bunga, nilai tukar, inflasi, produk domestik bruto (PDB) dan kebijakan pemerintah. Sementara faktor makro nonekonomi, misalnya, adalah peristiwa politik dalam negeri, peristiwa politik luar negeri, harga emas dunia, perang, demonstrasi massa, kasus lingkungan, dll. (Samsul, 2006).

Indonesia adalah produsen minyak kelapa sawit atau Crude Palm Oil (CPO) terbesar di dunia (Apriyani et al., 2016). Berdasarkan Indeks Mundi, produksi minyak sawit Indonesia mencapai 33 juta ton pada tahun 2014 (Apriyani et al., 2016). Setelah Indonesia, produsen minyak kelapa sawit terbesar kedua adalah Malaysia dengan total produksi 19,8 juta ton. Sebagai produsen CPO terbesar di dunia dan banyak negara lain yang membutuhkan CPO untuk keperluan industri, ini merupakan peluang bagi penerbit yang bergerak di bisnis perkebunan kelapa sawit untuk dapat meningkatkan total ekspor CPO ke negara lain yang pada akhirnya akan meningkatkan keuntungan perkebunan emiten sehingga kenaikan harga saham emiten perkebunan.

Berdasarkan uraian yang dinyatakan sebelumnya, kondisi ekonomi makro dapat tercermin dalam indeks harga saham di Bursa Efek Indonesia (BEI). Ini berarti bahwa asumsi bahwa variabel makroekonomi adalah faktor yang dapat mempengaruhi harga saham dalam hal ini adalah bahwa indeks harga saham diterima secara umum. Karena fenomena dan kebutuhan yang ada, penelitian ini diperlukan untuk memberikan analisis lebih lanjut tentang faktor-faktor yang mempengaruhi pergerakan IHSS Pertanian menggunakan data terbaru (up to date) sehingga hasil penelitian diharapkan dapat memberikan informasi yang bermanfaat dan dapat diandalkan untuk pihak yang bersangkutan.

\section{Kajian Pustaka}

Pergerakan indeks harga saham dipengaruhi oleh faktor internal dan eksternal. Faktorfaktor yang digunakan dalam penelitian ini didasarkan pada bukti empiris yang berkaitan dengan pergerakan indeks harga saham. Faktor-faktor ekonomi makro termasuk inflasi, nilai tukar USD / IDR, BI rate, IHSG, kondisi politik pemilu Indonesia, harga minyak sawit dunia, emas dunia harga, dan Indeks Dow Jones menjadi variable yang diperkirakan memberikan pengaruh terhadap pergerakan IHSS Pertanian.

Inflasi memiliki efek negatif pada pergerakan indeks harga saham. Inflasi menyebabkan harga naik, kenaikan harga barang sama dengan penurunan nilai mata uang. Inflasi akan mengurangi pendapatan riil masyarakat dan mengurangi daya beli masyarakat sebagai akibat dari penurunan penjualan produk dalam negeri yang menyebabkan penurunan profitabilitas perusahaan. Profitabilitas menurun menyebabkan harga saham perusahaan turun. Penelitian yang dilakukan oleh Kalyanaraman dan Tuwajri (2014), dan Barakat et al (2016) menemukan bahwa indeks harga konsumen (IHK) atau inflasi memiliki efek negatif pada indeks harga saham. Sedangkan Adam dan Tweneboah 
(2008), Issahaku et al (2013), dan Islam et al (2017) menemukan bahwa inflasi memiliki efek positif pada indeks harga saham.

Nilai tukar dalam hal ini adalah nilai tukar Rupiah terhadap Dolar AS secara negatif mempengaruhi pergerakan indeks harga saham. Peningkatan nilai tukar Rupiah terhadap Dolar AS atau depresiasi Rupiah berdampak pada kenaikan biaya produksi perusahaan yang mengandalkan impor untuk bahan baku dalam kegiatan bisnisnya. Selain itu, depresiasi Rupiah akan meningkatkan hutang luar negeri oleh perusahaan. Hasilnya adalah penurunan laba perusahaan. Laba perusahaan ini adalah salah satu indikator yang digunakan dalam menilai harga saham, penurunan laba juga akan mengurangi harga saham (Adam dan Tweneboah, 2008). Ini sesuai dengan penelitian Adam dan Tweneboah (2008), Witjaksono (2010), Kewal (2012), Mardiyati dan Rosalina (2013), Astuti dkk (2013), Mulyani (2014), Nordin et al (2014), Ullah et al (2014), Slamet et al (2016), dan Wijayaningsih et al (2016) menemukan bahwa nilai tukar memiliki pengaruh negatif terhadap indeks harga saham.

BI rate berpengaruh negatif pada pergerakan indeks harga saham. Peningkatan BI rate akan menyebabkan investor mengalihkan dana mereka ke sekuritas berbasis bunga seperti deposito. Investor akan mengubah portofolio mereka dengan menjual saham yang mengakibatkan penurunan harga saham. Selain itu, modal yang digunakan perusahaan yang akan mengembangkan bisnisnya biasanya dalam bentuk pinjaman atau hutang di bank. Jika perusahaan memperoleh pembiayaan dari hutang di bank, perusahaan akan menanggung beban bunga. Kenaikan suku bunga menyebabkan biaya modal meningkat sehingga profitabilitas perusahaan turun kemudian menurunkan harga saham. Penelitian yang dilakukan oleh Adam dan Tweneboah (2008), Witjaksono (2010), Hussain et al (2013), Astuti et al (2013), Mulyani (2014), Artha et al (2014), Nordin et al (2014), Ullah et al (2014), Wardani dan Andarini (2016), dan Wijayaningsih et al (2016) menemukan bahwa BI rate atau suku bunga berpengaruh negatif terhadap indeks harga saham.

IHSG diperkirakan memberikan pengaruh positif pada indeks sektoral, artinya peningkatan indeks IHSG akan mengakibatkan peningkatan indeks sektoral di Bursa Efek Indonesia. Hal ini disebabkan oleh sentimen positif investor menuju kondisi ekonomi Indonesia. Selain itu, menurut Samsul (2008), pergerakan indeks sektoral di pasar modal suatu negara dipengaruhi oleh indeks saham gabungan negara tersebut. Hal ini disebabkan oleh adanya kepercayaan dan harapan yang tinggi dari para investor terhadap pasar modal di suatu negara yang menyebabkan para investor percaya untuk berinvestasi di semua sektor di pasar modal.

Harga komoditas dalam hal ini adalah harga minyak sawit yang memiliki efek positif terhadap pergerakan indeks harga saham. Fluktuasi indeks harga saham sektor pertanian sangat ditentukan oleh pergerakan harga saham perusahaan perkebunan yang mayoritas bergerak dalam bisnis perkebunan kelapa sawit. Keuntungan perusahaan yang bergerak dalam bisnis perkebunan kelapa sawit juga ditentukan oleh harga minyak sawit (CPO) di pasar dunia di mana semakin tinggi harga $\mathrm{CPO}$, keuntungan perusahaan meningkat sehingga semakin banyak investor yang ingin membeli saham perusahaan yang menghasilkan peningkatan harga saham. Penelitian yang dilakukan oleh Nordin et al (2014) menemukan bahwa harga minyak sawit memiliki efek positif pada indeks harga saham.

Harga emas dunia memiliki pengaruh pada pergerakan indeks harga saham, baik secara keseluruhan maupun sektoral. Emas adalah instrumen investasi yang dipilih karena cenderung naik dan stabil. Emas juga merupakan alat yang dapat menangkal inflasi yang terjadi di suatu negara. Ketika akan berinvestasi, investor akan memilih jenis investasi yang memiliki tingkat pengembalian tinggi dengan risiko tertentu atau pengembalian tertentu dengan risiko 
rendah. Berinvestasi di pasar saham memiliki risiko lebih tinggi daripada berinvestasi di emas. Dengan risiko kerugian yang rendah dengan berinvestasi di emas dan harga emas dunia yang terus meningkat, ini menarik investor untuk berinvestasi di emas, sehingga mengurangi investasi di pasar modal dan mengakibatkan penurunan indeks harga saham karena penjualan saham. dimiliki oleh investor. Yahyazadehfar dan Babaie (2012) menggunakan faktor emas sebagai variabel ekonomi makro yang digunakan untuk mengukur harga saham di pasar modal.

\section{Metode Penelitian}

Jenis data yang digunakan dalam penelitian ini adalah data sekunder deret waktu dengan data bulanan dari Januari 2014 hingga Desember 2018. Data ini diperoleh dari berbagai sumber termasuk situs web Bursa Efek Indonesia, Bank Indonesia, Badan Pusat Statistik, dan Yahoo Finance. Data yang digunakan meliputi data inflasi, nilai tukar USD / IDR, BI rate, IHSG, kondisi politik pemilu Indonesia, harga minyak sawit dunia, harga emas dunia, dan Indeks Dow Jones.

Alat analisis yang digunakan adalah analisis regresi linier berganda Ordinary Least
Squares (OLS). OLS digunakan karena merupakan penaksir terbaik saat menganalisis data Anda. Dalam analisis data, penaksir terbaik mengacu pada BLUE (penaksir linier tidak bias terbaik). Berikut ini adalah model regresi OLS yang digunakan dalam penelitian ini

$$
\begin{aligned}
Y=\widehat{\beta_{0}}+\widehat{\beta_{1}} X_{1} & +\widehat{\beta_{2}} X_{2}+\widehat{\beta_{3}} X_{3}+\widehat{\beta_{4}} X_{4} \\
& +\widehat{\beta_{5}} X_{5}+\widehat{+\beta_{6}} X_{6}+\widehat{\beta_{7}} X_{7}+\widehat{\beta_{D}} X_{D} \\
& +\varepsilon
\end{aligned}
$$

Dimana $Y$ adalah IHSS Pertanian; $\beta_{0}$ adalah konstanta; $\beta_{1}, \beta_{2}, \beta_{3}, \beta_{4}, \beta_{5}, \beta_{6}, \beta_{7}, \beta_{\mathrm{D}}$ adalah koefisien variable bebas; $\mathrm{X}_{1}, \mathrm{X}_{2}, \mathrm{X}_{3}, \mathrm{X}_{4}, \mathrm{X}_{5}$, $\mathrm{X}_{6}, \mathrm{X}_{7}, \mathrm{X}_{\mathrm{D}}$ adalah Inflasi, Kurs USD/IDR, Suku Bunga BI, IHSG, Harga Minyak Kelapa Sawit Dunia, Harga Emas Dunia, Dow Jones Indeks, dan Keadaan Politik Pemilu Indonesia (variabel dummy); $\varepsilon$ adalah standard error.

Tahapan metode OLS meliputi uji asumsi klasik, model regresi uji kelayakan (uji F, uji $\mathrm{t}$, dan koefisien determinasi). Analisis dan pengujian regresi linier dilakukan dengan menggunakan perangkat lunak IBM SPSS Statistics 24.

\section{Hasil dan Pembahasan}

Perkembangan IHSS Pertanian selama periode 2014 sampai dengan 2018 ditunjukkan dalam Gambar 1. 


\section{IHSS Pertanian}

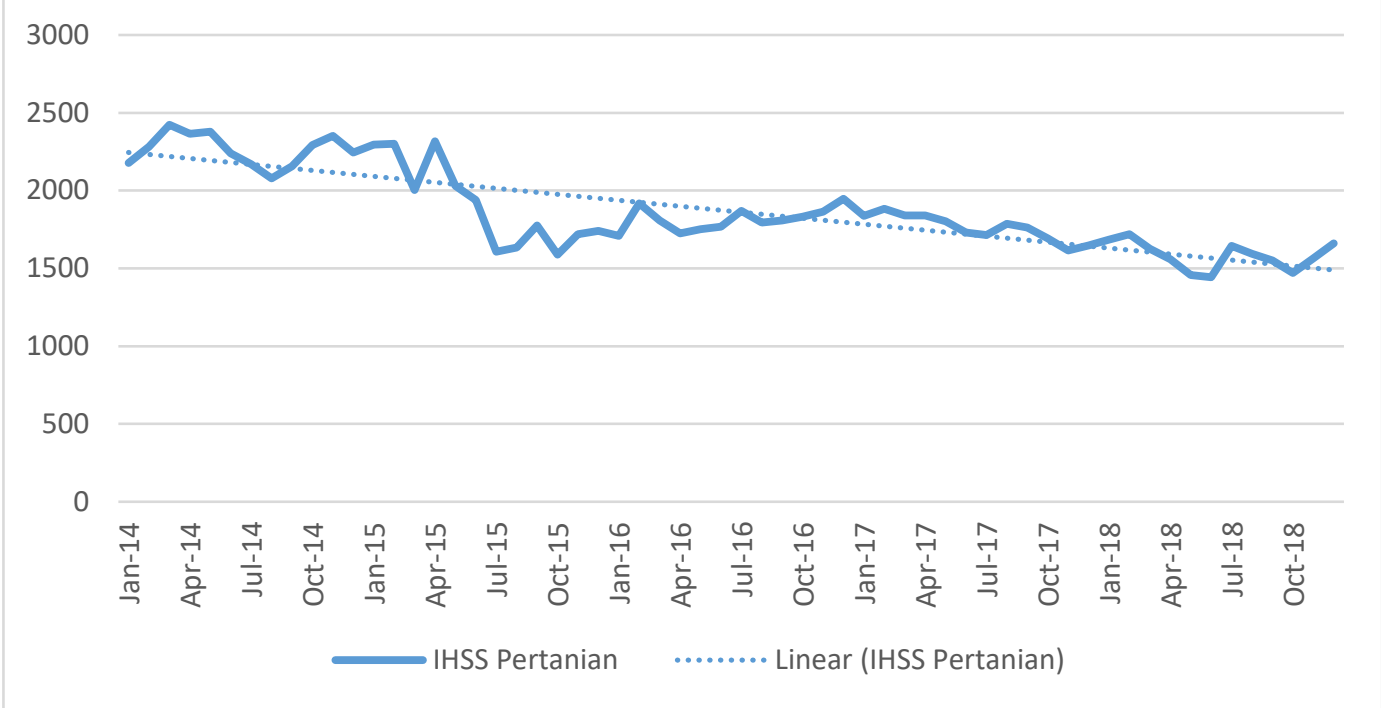

\section{Gambar 1. Perkembangan IHSS Pertanian Januari 2014 s/d Desember 2018 (Sumber:} Yahoo! Finance, 2018)

Pergerakan IHSS Pertanian pada periode penelitian cenderung mengalami penurunan. Titik tertinggi IHSS Pertanian terjadi pada Maret 2014 berada pada nilai 2242,81 dan titik terendah terjadi pada Juni 2018 berada pada level 1442,97. Total penurunan IHSS Pertanian dari Januari 2014 sampai dengan Desember 2018 adalah 33,47\%. Penurunan IHSS Pertanian merupakan yang paling parah jika dibandingkan dengan indeks saham sektoral lainnya.

IHSS Pertanian terdiri dari saham-saham perusahaan yang bergerak di bidang pertanian dalam arti luas, seperti perkebunan, peternakan, dan perikanan. Namun, mayoritas adalah perusahaan yang bergerak di perkebunan khususnya kelapa sawit. Penyebab turunnya nilai IHSS Pertanian pada periode 2014 sampai dengan 2018 cenderung disebabkan turunnya nilai saham emiten kelapa sawit yang memiliki bobot lebih besar terhadap pergerakan IHSS Pertanian.

Selanjutnya hasil analisis regresi faktor-faktor yang mempengaruhi Indeks Harga Saham Sektoral (IHSS) Pertanian, pada Tabel 2.

Tabel 2

Hasil Regresi

\begin{tabular}{|c|c|c|c|c|}
\hline \multicolumn{5}{|c|}{ Coefficients $^{a}$} \\
\hline \multirow[b]{2}{*}{ Model } & \multicolumn{2}{|c|}{ Unstandardized Coefficients } & \multirow[b]{2}{*}{$t$} & \multirow[b]{2}{*}{ Sig. } \\
\hline & $B$ & Std. Error & & \\
\hline (Constant) & 1963.657 & 1040.750 & 1.887 & .065 \\
\hline Inflasi & 29.240 & 12.212 & 2.394 & .020 \\
\hline KURS & -.138 & .048 & -2.895 & .006 \\
\hline Suku Bunga BI & 98.793 & 28.688 & 3.444 & .001 \\
\hline IHSG & 273 & .077 & 3.563 & .001 \\
\hline Harga kelapa sawit dunia & .885 & .314 & 2.817 & .007 \\
\hline Harga emas dunia & -.643 & .315 & -2.039 & .047 \\
\hline Indeks Dow Jones & -.013 & .020 & -.663 & .510 \\
\hline Kondisi politik pemilu Indonesia & -53.415 & 46.777 & -1.142 & .259 \\
\hline
\end{tabular}


Nilai signifikansi inflasi, nilai tukar USDR / IDR, suku bunga, IHSG, harga minyak sawit dunia, dan harga emas dunia menunjukkan nilai lebih kecil dari 0,05 , ini berarti bahwa variabel-variabel ini memiliki pengaruh yang signifikan terhadap pergerakan IHSS Pertanian . Suku bunga dan IHSG memiliki pengaruh paling signifikan $(0,001)$, diikuti oleh nilai tukar USD / IDR $(0,006)$, harga minyak sawit dunia $(0,007)$, inflasi $(0,020)$, dan harga emas dunia $(0,047)$.

Nilai koefisien inflasi berdasarkan hasil regresi linier berganda menunjukkan nilai positif. Ini memberikan pemahaman bahwa peningkatan inflasi dapat menyebabkan peningkatan IHSS Pertanian. Pengaruh positif bertentangan dengan hipotesis awal yang memperkirakan bahwa setiap penurunan inflasi akan diikuti oleh indeks harga saham di Indonesia (pengaruh negatif). Korelasi positif ini menurut pendapat Reilly dalam Wijayanti (2013) dengan asumsi inflasi yang terjadi adalah permintaan tarikan inflasi dimana dalam kondisi seperti itu kenaikan biaya produksi akan lebih besar dibebankan kepada masyarakat sehingga perusahaan masih dapat menikmati peningkatan laba yang memiliki dampak positif pada laporan keuangan dan kemampuan untuk membayar dividen. Sehingga memunculkan harapan positif pada saham perusahaan. Selain itu, investor juga dapat memperoleh capital gain dari selisih pembelian saat ini sebelum inflasi dengan harga saham ketika inflasi cenderung naik.

Nilai tukar dolar AS menunjukkan efek negatif dan signifikan terhadap IHSS Pertanian. Pengaruh negatif sesuai dengan hipotesis awal penelitian yang memperkirakan kenaikan nilai tukar dolar AS terhadap rupiah (depresiasi) menyebabkan penurunan IHSS Pertanian. Hasil penelitian ini juga didukung oleh Majid dan Yusof (2009), Thobarry (2009),
Issahaku et al (2013), Kalyanaraman dan Tuwajri (2014) yang menemukan bahwa nilai tukar memiliki efek negatif pada pergerakan indeks saham. Bagi perusahaan yang mengandalkan bahan baku impor, depresiasi rupiah akan menyebabkan biaya produksi meningkat, akibatnya laba perusahaan akan turun. Laba perusahaan merupakan salah satu faktor fundamental yang digunakan dalam menilai harga saham suatu perusahaan, turunnya laba akan memberikan sentimen negatif bagi investor untuk membeli saham suatu perusahaan, sehingga jika saham perusahaan sedikit tertarik, maka harga saham tersebut adalah sulit naik dan investor cenderung menjual menyebabkan penurunan harga saham. Depresiasi rupiah juga dapat meningkatkan utang luar negeri yang dimiliki oleh perusahaan.

Koefisien suku bunga BI menunjukkan pengaruh positif dan signifikan terhadap IHSS Pertanian. Pengaruh positif tersebut tidak sesuai dengan hipotesis awal penelitian yang memprediksi kenaikan suku bunga BI menyebabkan penurunan IHSS Pertanian. Hal ini sesuai dengan penelitian yang dilakukan oleh Gumilang dan Hidayat (2014) yang menemukan bahwa suku bunga BI menunjukkan pengaruh yang signifikan dan negatif terhadap indeks harga saham gabungan di Indonesia. Ini karena keuntungan investasi dalam bentuk perbankan akan meningkat ketika tingkat bunga meningkat. Jika banyak investor menjual saham mereka, itu akan menyebabkan harga saham turun dan begitu pula indeks harga saham.

Nilai koefisien IHSG menunjukkan pengaruh positif dan signifikan terhadap IHSS Pertanian. Pengaruh positif ini sesuai dengan hipotesis awal penelitian yang diprediksi terjadi peningkatan Komposit BEI yang menyebabkan peningkatan IHSS Pertanian. Peningkatan keseluruhan IHSG 
dapat memberikan sentimen positif terhadap subsektor yang termasuk dalam IHSG, baik pertanian maupun sub-sektor lainnya. Investor cenderung melakukan pengamatan dalam menentukan keputusan investasi berdasarkan pada prinsip-prinsip umum untuk spesifik, melihat pergerakan IHSG terlebih dahulu untuk kemudian menentukan sub-sektor mana yang menjadi pilihan untuk berinvestasi. Sehingga dengan masuknya modal investor ke suatu saham, maka dapat meningkatkan harga saham suatu perusahaan atau indeks.

Nilai koefisien harga minyak kelapa sawit dunia menunjukkan pengaruh positif dan signifikan terhadap IHSS Pertanian. Pengaruh positif sesuai dengan hipotesis awal penelitian yang memperkirakan bahwa kenaikan harga minyak sawit dunia menyebabkan peningkatan IHSS Pertanian. Ini konsisten dengan penelitian dengan penelitian yang dilakukan oleh Nordin et al (2014). Semakin tinggi harga CPO, semakin tinggi laba perusahaan yang bergerak dalam bisnis perkebunan kelapa sawit, semakin banyak investor yang ingin membeli saham perusahaan yang menghasilkan kenaikan harga saham.

Nilai koefisien emas menunjukkan pengaruh negatif dan signifikan terhadap IHSS Pertanian. Pengaruh negatif ini sesuai dengan hipotesis awal penelitian yang memprediksi kenaikan harga emas yang menyebabkan penurunan IHSS Pertanian. Emas adalah instrumen investasi yang dipilih karena tidak memiliki inflasi atau cenderung stabil. Jika harga emas naik di atas pengembalian investasi dalam saham, investor yang makan cenderung menggunakan modalnya untuk berinvestasi dalam emas daripada saham. Dengan keluarnya modal dari pasar saham, ada penjualan besar saham yang dapat menyebabkan penurunan harga saham sekuritas.

Tabel 3

Hasil Uji F

\begin{tabular}{|l|c|r|r|r|}
\hline \multicolumn{5}{|c|}{ Model Summary $^{b}$} \\
\hline Model & $R$ & $R$ Square & Adjusted $R$ Square & Std. Error of the Estimate \\
\hline 1 & $.942^{\mathrm{a}}$ & .886 & .869 & 97.20845 \\
\hline
\end{tabular}

a. Predictors: (Constant), POLITIK PEMILU INDONESIA, INFLASI, HARGA SAWIT DUNIA, HARGA EMAS DUNIA, SUKU BUNGA, IHSG, KURS, INDEKS DOW JONES

b. Variabel Dependen: IHSS PERTANIAN

Berdasarkan Tabel 3 di atas, nilai $\mathrm{R}^{2}=0,886$ diperoleh. Dengan demikian itu berarti bahwa pengaruh variabel inflasi, nilai tukar USD / IDR, suku bunga Bank Indonesia, IHSG, kondisi politik pemilu Indonesia, harga minyak sawit, harga emas, dan indeks DJIA dari IHSS Pergerakan pertanian adalah $88,6 \%$. Sisanya $11,4 \%$ dipengaruhi oleh faktor lain di luar model.

\section{Kesimpulan dan Saran}

\section{Kesimpulan}

Indeks Harga Saham Sektoral Pertanian periode 2014 sampai dengan 2018 secara simultan dipengaruhi oleh faktor inflasi, kurs USD/IDR, suku bunga Bank Indonesia, IHSG, kondisi politik pemilu Indonesia, harga minyak kelapa sawit, harga emas, dan indeks DJIA. Secara individual faktor yang memberikan pengaruh signifikan adalah faktor inflasi, kurs USD/IDR, suku bunga Bank Indonesia, IHSG, harga minyak kelapa sawit, dan harga 
emas. Sedangkan faktor kondisi politik pemilu Indonesia dan indeks DJIA tidak memberikan pengaruh yang signifikan. Kemampuan model dalam menjelaskan hubungan antara variabel terikat dengan independen tergolong tinggi dengan kesesuaian mencapai $88,6 \%$ dan sisanya $11,4 \%$ dipengaruhi oleh faktor-faktor lain di luar model.

\section{Saran}

Pengusaha di sektor pertanian, khususnya komoditas kelapa sawit harus dapat beradaptasi dengan melakukan diversifikasi bisnis, sehingga tidak hanya bergantung pada ekspor kelapa sawit yang sangat terpengaruh oleh harga kelapa sawit dunia yang sedang lesu. Selain itu, pemerintah perlu memaksimalkan kebijakan B20 sampai dengan B100 sehingga pemanfaatan hasil kelapa sawit Indonesia dapat dilakukan secara maksimal dan memberikan alternatif pasar bagi para pengusaha yang dapat meningkatkan profitabilitas perusahaan.

Riset ini memiliki keterbatasan dikarenakan hanya melakukan riset di salah satu sektor saja, yaitu pertanian. Eksplorasi pada riset-riset selanjutnya diharapkan dapat meneliti sektor lainnya yang menjadi komponen dalam IHSG, sehingga dapat memberikan informasi yang komprehensif bagi para investor yang ingin berinvestasi di sektor lainnya.

\section{Daftar Pustaka}

Amin, M. Z. (2012) 'Pengaruh Tingkat Inflasi, Suku Bunga SBI, Nilai Kurs Dollar (USD/IDR), Dan Indeks Dow Jones (DJIA) Terhadap Pergerakan Indeks Harga Saham Gabungan Di Bursa Efek Indonesia (Bei) (Periode 2008-2011)', Jurnal Skripsi FEB $U B$.

Bilson, C. M., Brailsford, T. J. and Hooper, V.J.(2001) 'Selecting macroeconomic variables as explanatory factors of emerging stock market returns', Pacific Basin Finance Journal. doi:
10.1016/S0927-538X(01)00020-8.

Buse, A. (1973) 'Goodness of fit in generalized least squares estimation', American Statistician. doi: 10.1080/00031305.1973.10479003.

Chen, N.-F., Roll, R. and Ross, S. A. (2002) 'Economic Forces and the Stock Market', The Journal of Business. doi: $10.1086 / 296344$.

Corradi, V., Distaso, W. and Mele, A. (2012)'Macroeconomic Determinants of Stock Market Volatility and Volatility Risk-Premiums', SSRN Electronic Journal.

Erdoğan, E. and Özlale, Ü. (2005) 'Effects Of Macroeconomic Dynamics On Stock Returns: The Case Of The Turkish Stock Exchange Market', Journal of Economic Cooperation, 26(2), pp. 69-90.

Gupta, R. and Modise, M. P. (2013) 'Macroeconomic Variables and South African Stock Return Predictability', Economic Modelling. doi: 10.1016/j.econmod.2012.10.015.

Jareño, F. and Negrut, L. (2016) 'US stock market and macroeconomic factors', Journal of Applied Business Research, 32(1), pp. 325-340. doi: 10.19030/jabr.v32i1.9541.

Kalu, E. and Okwuchukwu, O. (2014) 'Stock Market Return Volatility and Macroeconomic Variables in Nigeria', International Journal of Empirical Finance, 2(2), pp. 75-82. Available at: http://www.rassweb.com.

Kim, M. K. and Wu, C. (1987) 'Macroeconomic Factors and Stock Returns ', Journal of Financial Research. doi: 10.1111/j.1475-6803.1987.tb00481.x.

Listriono, K. and Nuraina, E. (2015) 'Peranan Inflasi, BI Rate, Kurs Dollar 
(USD/IDR) dalam Mempengaruhi Indeks Harga Saham Gaungan (IHSG)', Jurnal Dinamika Manajemen. doi: 10.15294/jdm.v6i1.4298.

Odularu, G. O. (2007) Crude Oil and the Nigerian Economic Performance, Oil and Gas Business.

Osei, K. A. (2006) 'Macroeconomic Factors and the Ghana Stock Market', The African Finance Journal, 8, pp. 2638.

Poon, S. and Taylor, S. J. (1991) 'Macroeconomic Factors and The UK Stock Market', Journal of Business Finance \& Accounting, 18(5), pp. 619-636. doi: 10.1111/j.14685957.1991.tb00229.x.

Rjoub, H., Türsoy, T. and Günsel, N. (2009a) 'Studies in Economics and Finance The effects of macroeconomic factors on stock returns: Istanbul Stock Market The effects of macroeconomic factors on stock returns: Istanbul Stock Market', Studies in Economics and Finance The Journal of Risk Finance Iss The Journal of Risk Finance, 26(4), pp. 36-45.

Rjoub, H., Türsoy, T. and Günsel, N. (2009b) 'The effects of macroeconomic factors on stock returns: Istanbul stock market', Studies in Economics and Finance. doi: 10.1108/10867370910946315.

Syarif, M. and Asandimitra, N. (2015) 'Pengaruh Indikator Makro Ekonomi dan Faktor Global Terhadap Indeks Harga Saham Gabungan (IHSG)', Jurnal Studi Manajemen.

Tangjitprom, N. (2011) Macroeconomic Factors of Emerging Stock Market: The Evidence from Thailand, SSRN. doi: 10.2139/ssrn.1957697.

Witjaksono, A. A. (2010) Analisis Pengaruh Tingkat Suku Bunga SBI, Harga Minyak Dunia, Harga Emas Dunia, Kurs Rupiah, Indeks Nikkei 225, dan Indeks Dow Jones terhadap IHSG, Tesis Universitas Diponegoro.

Zhu, B. (2012) 'The Effects of Macroeconomic Factors on Stock Return of Energy Sector in Shanghai Stock Market', International Journal of Scientific and Research Publications.

Zulbetti, R., K. Prihartono, A. H. and Perwito, P. (2015) 'Financial Performance, Macroeconomic Factors and Stock Return', in. doi: 10.2991/iceb-15.2015.14. 